\title{
The influence of whistleblowing system toward fraud prevention
}

\author{
Windy Yulian Maulida ${ }^{1 *}$, Bunga Indah Bayunitri ${ }^{2}$ \\ Widyatama University, Bandung, Indonesia ${ }^{1,2}$ \\ windy.yulian@widyatama.ac.id ${ }^{1}$, bunga.indah@widyatama.ac.id ${ }^{2}$
}

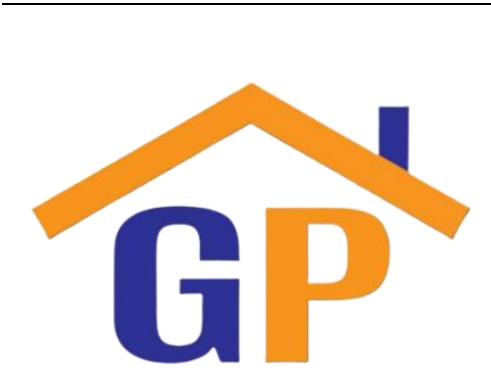

Article History

Received on 14 July 2020

$1^{\text {st }}$ Revision on 10 August 2020

$2^{\text {nd }}$ Revision on 2 September 2020

Accepted on 3 September 2020

\begin{abstract}
Purpose: This study aimed to determine the implementation of whistleblowing system and fraud prevention, and to find out how the whistleblowing system affects fraud prevention at the Jabar Banten Central Bank in Bandung.
\end{abstract}

Research Methodology: This study used the explanatory method and simple linear regression analysis. The program used was SPSS Version 19.00.

Results: The whistleblowing system affected fraud prevention by $54.3 \%$.

Limitation: The study is limited to the role of the whistleblowing system and fraud prevention.

Contribution: The results of this study contribute to improving the application of the whistleblowing system and preventing fraud.

Keywords: Whistleblowing system, Fraud prevention

How to cite: Maulida, W. Y., \& Bayunitri, B. I. (2021). The influence of whistleblowing system toward fraud prevention. International Journal of Financial, Accounting, and Management, 2(4), 275-294.

\section{Introduction}

In Indonesia, banks must implement corporate governance. First, banks assume a dominant role in the economy, especially as an engine of economic growth. Second, competition in the banking industry which is currently very competitive encourages business players in the industry to maintain and improve their competitiveness by making the best possible business structure. Third, banking industry is an industry that involves quite complex business activities where the focus of the business is managing finances with a quite high risk. Fourth, banking industry is a "trust" industry. As a business player in the field of financial services, building and maintaining the confidence and trust of the community and the international world is the main thing that must be owned and maintained by banks which is as an absolute condition in competing in this industry. Therefore, to realize the application of adequate corporate governance, banks must always be guided by the principles of good corporate governance (Alfian, Subhan, \& Rahayu, 2018).

Internal control for an organization can maintain wealth and fluency, to avoid undesirable things such as fraud. Based on a survey conducted by Indonesian Association of Certified Fraud Examiners (ACFE) in 2016, the most common fraud in Indonesia is corruption (Association of Certified Fraud Examiners Indonesia Chapter, 2016). Based on the results of the ACFE survey in 2014, banks and other financial institutions were the sectors with the highest rates of fraud (Association of Certified Fraud Examiners, 2018). Based on Anti-Fraud Control published by ACFE in 2016, the best and most effective fraud prevention method is through the Whistleblowing System mechanism.

The anti-fraud strategy for conventional and Islamic banks in its application is in the form of detection and prevention. Detection and prevention are part of a fraud control system that contains steps to identify and find fraud in the Bank's business activities, which includes at least the Whistleblowing policy, surprise audit, and surveillance system. It includes at least policies and mechanisms including the application of the Whistleblowing System that has been regulated in Director Regulation No. 
002/PBSG-SKAI/DIR/IV/2017 on Company Guidelines for Reporting System of Violations through the Whistleblowing System (WBS) (Association of Certified Fraud Examiners Indonesia Chapter, 2016). An effective Whistleblowing System will encourage community participation and company employees to be more willing to act to prevent fraud and corruption by reporting it to those who can handle it. This means that Whistleblowing System can reduce the culture of "silence" towards the culture of "honesty and openness" (Komite Nasional Kebijakan Governance, 2008).

Jabar Banten Bank was also involved in the case of fictitious credit in 2014-2016 against PT. Hastuka Sarana Karya (HSK). Police Criminal Investigation Agency determined two suspects in the fictitious credit case of Rp548 billion in BJB Sharia Bank in the name of Arif Budirahardja as the Head of Sharia BJB Bank Financing Division and Yasril Narapraya as the Retail Head Group of BJB Sharia Bank. The Director of Corruption Crimes (Dit Tipikor) of the Indonesian National Police, Brigadier General Pol Erwanto Kurniadi, said that investigators had sent the two suspects' Notification Letter on the Commencement of Investigation of the two suspects to the Attorney General's Office to follow the progress of the case investigation which caused state financial losses amounting to Rp548 billion. In this case, Police Criminal Investigation Agency has appointed a former acting (Plt) President Director of Sharia Jabar Banten Bank named Yocie Gusman as the suspect in the alleged corruption case of using BJBS loans to debtors on behalf of PT. Hasuka Sarana Karya in 2014-2016. The loan was later known to be carried out without collateral. The debtor, PT. HSK, instead pledgeds the parent land and other bank buildings. After being disbursed, it turned out that the credit payment was bad at Rp.548 billion.

The results of a survey conducted by the Institute of Business Ethics concluded that one of four employees knew about the incident, but more than half $(52 \%)$ of those who knew the violation remained silent and did nothing. Reluctance to report known violations can be resolved through the implementation of an effective, transparent and responsible Whistleblowing System. This system is expected to increase the level of employees' participation in reporting violations. Its effectiveness can be seen from the number of frauds that have been detected and prevented as well as the relatively shorter time to act compared to other methods (Alfian et al., 2018).

Related to the above phenomenon, the existence of the Whistleblowing System can encourage public participation and bank employees to be more open and act to report fraud to prevent irregularities to parties who can handle it, and can minimize the occurrence of fraud that is not too large. Weak implementation of Whistleblowing System can hinder the disclosure of violations that occur within a company (Merdikawati \& Prastiwi, 2012).

\section{Literature review and hypotheses development}

\subsection{Fraud}

Fraud can be defined as cheating that means an irregularity and unethical acts performed deliberately for a particular reason, such as cheating or misleading other parties, performed by good people from inside and outside the organization. Fraud is designed to exploit opportunities dishonestly, which directly or indirectly harm other parties (Karyono, 2013:4). Based on the Fraud Triangle Theory in Karyono (2013:9) which was first coined by Dr. Donald Cressy, co-founder of ACFE, mentioned that fraud behavior is supported by three elements, those are:

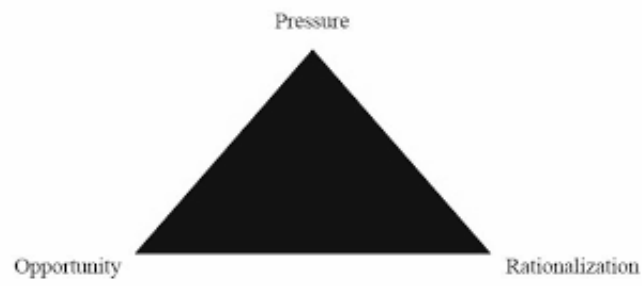

Figure 1: Fraud Triangle Theory 
1. Pressure

The urge to commit fraud occurs in employees (employee fraud) and managers (management fraud) through the encouragement of:
a. Financial pressures;
b. Bad habits;
c. Work Environment Pressure;
d. Other Pressure.

\section{Opportunity}

Opportunities arise mainly because of weak internal controls to prevent fraud. Opportunities can also occur because of the valley of penalty, and the inability to assess the quality of performance. Several factors can lead to the opportunities to commit fraud, namely:

a. Failure to bring order to the perpetrators of fraud.

b. Limited access to information.

c. Ignorance, lazy and not according to the ability of employees.

d. Lack of audit trail.

\section{Rationalization}

a. Perpetrators assume that what is done is normal for other people to do.

b. The perpetrator feels that he has contributed greatly to the organization and he should receive more than he has received.

c. The perpetrator considers his good intention is to overcome the problem, later it will be returned.

Association of Certified Fraud Examiners Indonesia Chapter (2016) in Kennedy and Siregar (2017:2) divides fraud into three types or typologies based on actions, namely:

1. Asset Misappropriation. This form involves misuse or theft of company or other parties' assets or property. This is the easiest type of fraud to detect as tangible or measurable (defined value).

2. Fraudulent Statements. It requires measures taken by a corporation or government agency's officials or executives to conceal the actual financial situation by performing financial engineering in presenting benefit financial statements.

3. Corruption. This action frequently takes place in developing countries where law-enforcement is poor and where there is still no knowledge of good governance to challenge the honesty factor. This form of fraud is also not observable because the parties working together to share the benefits (mutual symbiosis). This includes misuse of interest authority/ conflicts, bribery, unlawful gratuities, and economic coercion.

\subsection{Whistleblowing System}

According to Jabar Banten Bank Whistleblowing System, the whistleblowing system at Jabar Banten Bank is defined as a complaint mechanism for submitting, managing and following up on reports of alleged violations committed by internal and external parties of Jabar Banten Bank. For those who want to report indications of violations by Jabar Banten Bank employees but worried that their identities will be revealed, can submit it on hotline column of the Jabar Banten Bank Whistleblowing System website.

Jabar Banten Bank Whistleblowing System (bjbWBS) (2020) revealed that the benefits of the Whistleblowing System in Jabar Banten Bank are:

1. to make it easy to see various kinds of fraud committed internally by BJB Bank.

2. to make it easy for people to do reporting by only accessing the bjbWBS website. 
The Whistleblower mechanism in the Banten West Java Bank Whistleblowing System discloses the mechanism for reporting violations such as what must be reported, namely:

1. Cheating

2. Theft

3. Manipulation or Counterfeiting

4. Corruption, including in the form of; conflicts of interest, gratification and bribery.

5. Extortion

6. Fraud

7. Criminal acts in the banking sector, and

8. Other similar actions, namely symptoms of types of actions that are threatened with criminal penalties related to bank operations.

In the legal context, the presence of Whistleblowers in Indonesia needs to be protected, so that corruption cases can be dismantled. However, in the practice it is not easy, because if a whistleblower is proven guilty legally, the whistleblower cannot be acquitted of criminal charges.

\section{Previous Research}

Table 1: Previous Research

\begin{tabular}{|c|c|c|c|c|c|}
\hline No & Author & Title & Variable & Results & Differences \\
\hline 1. & $\begin{array}{l}\text { I Gede Adi } \\
\underline{\text { Kusuma, }} \\
\underline{\text { Edy Sujana }} \\
\underline{\text { \& Made Ari }} \\
\underline{\text { Wahyuni }} \\
\underline{(2017)} \\
\text { Journal of } \\
\text { Accounting } \\
\text { S1 Program } \\
\text { (Vol.8 No. } \\
2 \text { Th 2017) }\end{array}$ & $\begin{array}{l}\text { The Influence } \\
\text { of Internal } \\
\text { Control, } \\
\text { Whistleblowin } \\
\text { g System and } \\
\text { the Morality of } \\
\text { the Apparatus } \\
\text { on Fraud } \\
\text { Prevention }\end{array}$ & $\begin{array}{l}\mathrm{X}_{1}: \text { Internal } \\
\text { Control } \\
\mathrm{X}_{2}: \\
\text { Whistleblowin } \\
\mathrm{g} \text { System } \\
\mathrm{X}_{3}: \text { Morality of } \\
\text { the Apparatus } \\
\mathrm{Y}: \text { Fraud } \\
\text { Prevention }\end{array}$ & $\begin{array}{l}\text { Internal Control, } \\
\text { Whistleblowing } \\
\text { System and } \\
\text { Apparatus Morality } \\
\text { had positive and } \\
\text { significant effect on } \\
\text { fraud prevention. }\end{array}$ & $\begin{array}{l}\text { The difference lies in } \\
\text { the independent } \\
\text { variables used, in } \\
\text { which previous } \\
\text { studies use } \\
\text { independent variables } \\
\text { of internal control } \\
\text { and apparatus } \\
\text { morality. }\end{array}$ \\
\hline 2. & $\begin{array}{l}\frac{\text { Atmadja, }}{\text { A.T., }} \\
\frac{\text { Saputra, }}{\text { K.A.K., }} \\
\frac{\text { Manurung, }}{\text { Daniel }} \\
\underline{\text { T.H., }} \\
\underline{(2019)} \\
\text { Widyatama } \\
\text { Lecturer } \\
\text { Journal }\end{array}$ & $\begin{array}{l}\text { Proactive } \\
\text { fraud audit, } \\
\text { whistleblowin } \\
\mathrm{g} \text { and cultural } \\
\text { implementatio } \\
\mathrm{n} \text { of tri hita } \\
\text { karana for } \\
\text { fraud } \\
\text { prevention }\end{array}$ & $\begin{array}{l}\mathrm{X}_{1}: \text { Proactive } \\
\text { fraud audit } \\
\mathrm{X}_{2}: \\
\text { whistleblowing } \\
\mathrm{X}_{3} \text { :cultural } \\
\text { implementation } \\
\mathrm{Y} \text { : fraud } \\
\text { prevention }\end{array}$ & $\begin{array}{l}\text { The results of this } \\
\text { study were } \\
\text { proactive fraud } \\
\text { audit and tri hita } \\
\text { kara culture that } \\
\text { significantly } \\
\text { influenced fraud } \\
\text { prevention in } \\
\text { village funding } \\
\text { management, while } \\
\text { whistleblowing } \\
\text { variable did not } \\
\text { show a significant } \\
\text { influence on village } \\
\text { funding } \\
\text { management fraud } \\
\text { prevention. }\end{array}$ & $\begin{array}{l}\text { The difference lies in } \\
\text { the dependent } \\
\text { variable } x_{1} \text { and } X_{3} \\
\text { used, in which } \\
\text { previous studies use } \\
\text { the dependent } \\
\text { variable of proactive } \\
\text { fraud audit and } \\
\text { cultural } \\
\text { implementation. }\end{array}$ \\
\hline 3. & $\begin{array}{l}\text { Nurfadillah, } \\
\underline{\text { Herra }}\end{array}$ & $\begin{array}{l}\text { Effect of } \\
\text { Whistleblowin } \\
\text { g System }\end{array}$ & $\begin{array}{l}\mathrm{X}_{1}: \\
\text { Whistleblowin } \\
\text { g System }\end{array}$ & $\begin{array}{l}\text { The } \\
\text { implementation of } \\
\text { Whistleblowing }\end{array}$ & $\begin{array}{l}\text { The difference lies in } \\
\text { the case study used } \\
\text { by previous research }\end{array}$ \\
\hline
\end{tabular}




\begin{tabular}{|c|c|c|c|c|c|}
\hline & $(2018)$ & $\begin{array}{l}\text { Implementatio } \\
\text { n on Fraud } \\
\text { Prevention. } \\
\text { Study of the } \\
\text { Office of } \\
\text { Customs and } \\
\text { Excise } \\
\text { Customs and } \\
\text { Excise Type A } \\
\text { Bandung }\end{array}$ & $\begin{array}{l}\text { Y : Fraud } \\
\text { Prevention }\end{array}$ & $\begin{array}{l}\text { System had a } \\
\text { significant effect on } \\
\text { fraud prevention } \\
\text { and contributes to } \\
\text { the effect by } \\
39.6 \% \text {. }\end{array}$ & $\begin{array}{l}\text { at the Office of } \\
\text { Supervision of } \\
\text { Customs and Excise } \\
\text { Service Type A } \\
\text { Customs Bandung. } \\
\text { Mean while, the } \\
\text { current case study } \\
\text { was conducted at } \\
\text { Jabar Banten Bank } \\
\text { Bandung. }\end{array}$ \\
\hline 4. & $\begin{array}{l}\underline{\text { Sabdelino, }} \\
\underline{\text { Sachli }} \\
\underline{(2016)}\end{array}$ & $\begin{array}{l}\text { The Influence } \\
\text { of Internal } \\
\text { Auditors in the } \\
\text { Implementatio } \\
\mathrm{n} \text { of } \\
\text { Whistleblowin } \\
\text { g System } \\
\text { Against } \\
\text { Cheating } \\
\text { Prevention }\end{array}$ & $\begin{array}{l}X_{1} \text { : Internal } \\
\text { Auditors } \\
X_{2}: \\
\text { Whistleblowin } \\
\text { g System } \\
\text { Y : Cheating } \\
\text { Prevention }\end{array}$ & $\begin{array}{l}\text { The strong } \\
\text { relationship } \\
\text { between the } \\
\text { influences of } \\
\text { internal auditors in } \\
\text { the application of } \\
\text { Whistleblowing } \\
\text { System on fraud } \\
\text { prevention. The } \\
\text { amount of } \\
\text { influence was } \\
41.4 \%\end{array}$ & $\begin{array}{l}\text { The difference lies in } \\
\text { the independent } \\
\text { variable X1 used, in } \\
\text { which previous study } \\
\text { use the independent } \\
\text { variable of internal } \\
\text { auditors. }\end{array}$ \\
\hline 5. & $\begin{array}{l}\frac{\text { BI }}{\text { Bayunitri, }} \\
\underline{\mathrm{A}} \\
\underline{\text { Christinawa }} \\
\underline{\mathrm{i}} \\
\underline{(2019)} \\
\text { Widyatama } \\
\text { Lecturer } \\
\text { Journal }\end{array}$ & $\begin{array}{l}\text { The Influence } \\
\text { of Internal } \\
\text { Auditor Skills } \\
\text { on Fraud } \\
\text { Detection } \\
\text { (Survey at PT. } \\
\text { Bank Mandiri } \\
\text { of Soekarno } \\
\text { Hatta Branch, } \\
\text { Bandung) }\end{array}$ & $\begin{array}{l}\mathrm{X}_{1} \text { : Internal } \\
\text { Audit Skills } \\
\mathrm{Y}: \text { Fraud } \\
\text { Detection }\end{array}$ & $\begin{array}{l}\text { Internal auditor } \\
\text { activities could } \\
\text { reduce } 35 \% \text { of } \\
\text { fraud. Therefore the } \\
\text { role of competent } \\
\text { internal auditors is } \\
\text { very important in } \\
\text { detecting and } \\
\text { preventing fraud. }\end{array}$ & $\begin{array}{l}\text { The difference lies in } \\
\text { the dependent } \\
\text { variable X1 used, in } \\
\text { which previous study } \\
\text { use the dependent } \\
\text { variable of internal } \\
\text { audit skills while the } \\
\text { independent variable } \\
\text { X2 used was } \\
\text { detection. }\end{array}$ \\
\hline 6. & $\begin{array}{l}\frac{\text { Rizky }}{\text { Ramdhani }} \\
\underline{(2018)}\end{array}$ & $\begin{array}{l}\text { The Effect of } \\
\text { Internal Audit } \\
\text { and } \\
\text { Whistleblowin } \\
\text { g System on } \\
\text { Fraud } \\
\text { Prevention } \\
\text { (Study at PT. } \\
\text { PLN Bandung } \\
\text { City) }\end{array}$ & $\begin{array}{l}X_{1} \text { : Internal } \\
\text { Audit } \\
X_{2}: \\
\text { Whistleblowin } \\
\text { g System } \\
\text { Y : Fraud } \\
\text { Prevention }\end{array}$ & $\begin{array}{l}\text { Internal Audit and } \\
\text { Whistleblowing } \\
\text { System affected } \\
\text { Fraud Prevention }\end{array}$ & $\begin{array}{l}\text { The difference lies in } \\
\text { the independent } \\
\text { variable X1 used, in } \\
\text { which previous } \\
\text { studies use the } \\
\text { independent variable } \\
\text { of internal auditors. } \\
\text { Meanwhile, the } \\
\text { difference in previous } \\
\text { research case studies } \\
\text { was conducted at PT. } \\
\text { PLN Bandung City } \\
\text { while recent case } \\
\text { studies was } \\
\text { conducted at the } \\
\text { West Java Banten } \\
\text { Central Bank } \\
\text { Bandung. }\end{array}$ \\
\hline
\end{tabular}




\begin{tabular}{|c|c|c|c|c|c|}
\hline 7. & $\begin{array}{l}\frac{\text { Rozmita }}{\text { Dewi Y. }} \\
\frac{(2017)}{\text { Journal }} \\
\text { Internationa } \\
1 \\
\text { Vol. } 20 \\
\text { No.1 }\end{array}$ & $\begin{array}{l}\text { The Effect of } \\
\text { Internal Contol } \\
\text { and Anti- } \\
\text { Fraud } \\
\text { awareness on } \\
\text { Fraud } \\
\text { Prevention (A } \\
\text { Survey on } \\
\text { Intergovernme } \\
\text { ntal } \\
\text { Organizations) }\end{array}$ & $\begin{array}{l}\mathrm{X}_{1}: \text { Internal } \\
\text { Control } \\
\mathrm{X}_{2}: \text { Anti- } \\
\text { Fraud } \\
\text { Awareness } \\
\mathrm{Y}: \text { Fraud } \\
\text { Prevention }\end{array}$ & $\begin{array}{l}\text { The results showed } \\
\text { that internal control } \\
\text { and anti-fraud } \\
\text { awareness had } \\
\text { significant effects } \\
\text { on fraud } \\
\text { prevention. It } \\
\text { indicated that the } \\
\text { action of doing } \\
\text { fraud can be } \\
\text { prevented by } \\
\text { establishing a good } \\
\text { internal control and } \\
\text { increasing anti- } \\
\text { fraud awareness to } \\
\text { all parties in the } \\
\text { organization. }\end{array}$ & $\begin{array}{l}\text { The difference lies in } \\
\text { the dependent } \\
\text { variable X1 and X2 } \\
\text { used, in which } \\
\text { previous study use } \\
\text { the dependent } \\
\text { variable of internal } \\
\text { control and anti-fraud } \\
\text { awareness. }\end{array}$ \\
\hline 8. & $\begin{array}{l}\frac{\text { Imang D. }}{\text { P.., Imam }} \\
\frac{\text { Ghozali, }}{\text { Tarmizi }} \\
\underline{\text { Achmad. }} \\
\underline{(2017)} \\
\text { Internationa } \\
1 \text { Journal of } \\
\text { Civil } \\
\text { Engineering } \\
\text { and } \\
\text { Technology } \\
\text { Vol.8 Issue } \\
10\end{array}$ & $\begin{array}{l}\text { The Effects of } \\
\text { the } \\
\text { Whistleblowin } \\
\text { g System on } \\
\text { Financial } \\
\text { Statement } \\
\text { Fraud Ethical } \\
\text { Behavior As } \\
\text { the Mediators }\end{array}$ & $\begin{array}{l}X_{1}: \\
\text { Whistleblowin } \\
\text { g System } \\
\text { Y: Financial } \\
\text { Statement } \\
\text { Fraud Ethical } \\
\text { Behavior }\end{array}$ & $\begin{array}{l}\text { Whistleblowing } \\
\text { System had } \\
\text { positive influence } \\
\text { on the prevention } \\
\text { of financial } \\
\text { reporting fraud is } \\
\text { acceptable. } \\
\text { Whistleblowing } \\
\text { System Positive } \\
\text { Influence on } \\
\text { Trends Financial } \\
\text { fraud through } \\
\text { Ethical Behavior is } \\
\text { unacceptable }\end{array}$ & $\begin{array}{l}\text { The difference lies in } \\
\text { the dependent } \\
\text { variable X1 used, in } \\
\text { which previous study } \\
\text { used the dependent } \\
\text { variable of financial } \\
\text { reporting fraud } \\
\text { ethical behavior. }\end{array}$ \\
\hline 9. & $\begin{array}{l}\underline{\text { I Gusti Ayu }} \\
\underline{\text { Purnamawa }} \\
\underline{\text { ti, }} \\
\frac{(2018)}{\text { Jurnal }} \\
\text { Keuangan } \\
\text { dan } \\
\text { Perbankan } \\
\text { Vol. 22, } \\
\text { No. 2, April } \\
\text { 2018: 362- } \\
372\end{array}$ & $\begin{array}{l}\text { Individual } \\
\text { Perception of } \\
\text { Ethical } \\
\text { Behavior and } \\
\text { Whistleblowin } \\
\text { g on Fraud } \\
\text { Detection } \\
\text { through Self- } \\
\text { Efficacy }\end{array}$ & $\begin{array}{l}\mathrm{X}_{1} \text { : Ethical } \\
\text { Behavior } \\
\mathrm{X}_{2} \text { : } \\
\text { Whistleblowin } \\
\text { g System } \\
\mathrm{Y}: \text { Fraud } \\
\text { Detection }\end{array}$ & $\begin{array}{l}\text { Positive and } \\
\text { significant effect of } \\
\text { Whistleblowing } \\
\text { and self-efficacy } \\
\text { towards detection }\end{array}$ & $\begin{array}{l}\text { The difference lies in } \\
\text { the independent } \\
\text { variables which was } \\
\text { individual perception } \\
\text { of behavior and the } \\
\text { dependent variable } \\
\text { was Fraud Detection. }\end{array}$ \\
\hline 10. & $\begin{array}{l}\text { Novatiani, } \\
\text { R. Ait } \\
\text { Julaeha, } \\
\text { Eha. }\end{array}$ & $\begin{array}{l}\text { Internal Audit } \\
\text { Influence on } \\
\text { Fraud } \\
\text { Prevention (a } \\
\text { case study at } \\
\text { PT. Pindad, }\end{array}$ & $\begin{array}{l}\mathrm{X}_{1} \text { : Internal } \\
\text { Audit } \\
\text { Y:Fraud } \\
\text { Prevention }\end{array}$ & $\begin{array}{l}\text { The conclusion of } \\
\text { this research was } \\
\text { that adequate } \\
\text { internal audit with } \\
89 \% \text {, adequate } \\
\text { fraud prevention by }\end{array}$ & $\begin{array}{l}\text { The difference lies in } \\
\text { the independent } \\
\text { variable X1 used in } \\
\text { previous studies } \\
\text { added by the } \\
\text { independent variable }\end{array}$ \\
\hline
\end{tabular}




\begin{tabular}{|c|c|c|c|}
\hline $\begin{array}{l}\underline{(2013)} \\
\text { Widyatama } \\
\text { Lecturer } \\
\text { Journal }\end{array}$ & $\begin{array}{l}\text { Bandung, } \\
\text { Indonesia). }\end{array}$ & $\begin{array}{l}87 \% \text { and the } \\
\text { coefficient of } \\
\text { influence of } \\
\text { internal audit for } \\
\text { fraud prevention is } \\
0.791 \text {, it means the } \\
\text { relationship is in } \\
\text { the strong category. } \\
\text { The test results } \\
\text { with the } t \text { test } \\
\text { showed } t(3,662)> \\
(2,306) \text {, it means } \\
\text { showing to reject } \\
\text { Ho, which shows a } \\
\text { positive } \\
\text { relationship } \\
\text { between the effects } \\
\text { of internal audit on } \\
\text { prevention. }\end{array}$ & $\begin{array}{l}\text { of internal audit. } \\
\text { Previous case study } \\
\text { was carried out at PT. } \\
\text { Pindad Bandung } \\
\text { while the current case } \\
\text { study in Jabar Banten } \\
\text { Bank, Central } \\
\text { Bandung. }\end{array}$ \\
\hline
\end{tabular}

The relationship between whistleblowing system implementation and fraud prevention

Fraud is any illegal act characterized by fraud, concealment or abuse of trust. Such actions are not limited to threats or violations in the form of physical force. Fraud can be committed by parties and organizations to get money, assets, or services; to avoid payment or loss of services; or for personal or business gain (The Institute of Internal Auditors, 2017).

Anti-Fraud Control which was published based on the results of ACFE in 2016, the best and most effective fraud prevention method is through the Whistleblowing System mechanism. The anti-fraud strategy for conventional and Islamic banks in its application is in the form of detection and prevention. Detection and prevention are part of a fraud control system that contains steps to identify and find fraud in the Bank's business activities, which includes at least Whistleblowing policies, surprise audits, and surveillance systems (Association of Certified Fraud Examiners Indonesia Chapter, 2016).

An effective Whistleblowing System will encourage community participation and company employees to be more courageous to act to prevent fraud and corruption by reporting it to those who can handle it. This means that Whistleblowing System can reduce the culture of "silence" towards a culture of "honesty and openness". The effectiveness of Whistleblowing System can be seen from the number of cheats that have been detected and also the time to take action which is relatively shorter compared to other methods (Komite Nasional Kebijakan Governance, 2008). A study result shows that more fraud was detected through information from fellow employees than was found by auditor.

\section{Framework}

The problem of fraud that occurs within a company reflects that there are functions within the company that are not implemented properly. The impact of corporate governance becomes unhealthy. Therefore, it is necessary to prevent fraud as early as possible to avoid this practice. The factor that can prevent fraud is the Whistleblowing System. One of the internal controls to prevent fraud in a company is the implementation of the whistleblowing system because by its implementation, employees and parties who will commit fraud will arise a sense of reluctance due to an effective reporting system in financial reporting (Semendawai et al., 2011).

\section{Research hypothesis}

Jabar Banten Bank has implemented a whistleblowing system by accessing it through bjbWBS.com. Previous research regarding the whistleblowing system was conducted by Wijaya (2019) with the title 2021 | International Journal of Financial, Accounting, and Management/ Vol 2 No 4, 275-294 
of "The Effect of Internal Audit and Whistleblowing System on Fraud Prevention at PT Bank x Tbk". The results of this study indicated that the whistleblowing system had a significant positive effect on fraud prevention by $67 \%$, indicating the whistleblowing system simultaneously affected fraud prevention. Another research was conducted by Libramawan (2014) with the title of "The Effect of Whistleblowing System Implementation on Fraud Prevention" in a survey study at PT Coca-Cola Amatil Indonesia SO Bandung. Based on the results of this study, it showed that the magnitude of the application of the whistleblowing system in contributing to the influence of fraud prevention is not too large. This is because there are still some employees who were still in doubt that the implementation of the whistleblowing system will make it easier for them to convey violations that have occurred in the company. Based on the explanation of the framework of thought, the hypotheses tested in this study are:

\section{H1: The application of the Whistleblowing System has an effect on fraud prevention.}

\section{Research methodology}

This study used an explanatory research method. The author obtained data from Jabar Banten Central Bank in Bandung. The time of the study was conducted from June to July 2020. The object of research in this study was the internal audit unit division, the risk management division, the strategic planning division, and the legal division in implementing the whistleblowing system and preventing fraud at Jabar Banten Central Bank in Bandung. The population in this study were 43 people, including: 12 people from the internal audit unit division, 10 people from the risk management division, 12 people from the strategic planning division, and 9 people from the legal division.

To determine the sample size of a population, there are various methods proposed by experts, including by using Slovin method quoted from Umar (2010:146). In this study, the population obtained 43 people. The error rate was set at $10 \%$, then:

$$
\begin{gathered}
\eta=\frac{43}{1+43(0,10)^{2}} \\
\eta=\frac{43}{1,43} \\
\eta=30
\end{gathered}
$$

From the calculations above it can be seen that the number of samples to be investigated was 30 employees at the Jabar Banten Central Bank in Bandung.

\subsection{Data collection method}

Data collection technique used in this study were:

1. Field Research

In this study, the authors tried to colect data through observation, namely the collection of data collected by direct observation of the object being studied. In this study the researchers used a

\begin{tabular}{|c|c|c|c|c|c|c|}
\hline \multirow[b]{2}{*}{ No. } & \multirow[b]{2}{*}{ Questions } & \multicolumn{5}{|c|}{ Answers } \\
\hline & & $\begin{array}{c}\text { STRONGLY } \\
\text { AGREE }\end{array}$ & AGREE & DOUBTFUL & DISAGREE & $\begin{array}{l}\text { STRONGLY } \\
\text { DISAGREE }\end{array}$ \\
\hline \multicolumn{7}{|c|}{ Company and Employee Commitments } \\
\hline 1 & $\begin{array}{l}\text { You are aware and understand that it is useful } \\
\text { and important to implement a whistleblowing } \\
\text { system program that is useful in preventing } \\
\text { fraud. }\end{array}$ & & & & & \\
\hline
\end{tabular}
questionnaire.

\section{WHISTLEBLOWING SYSTEM (X1)}




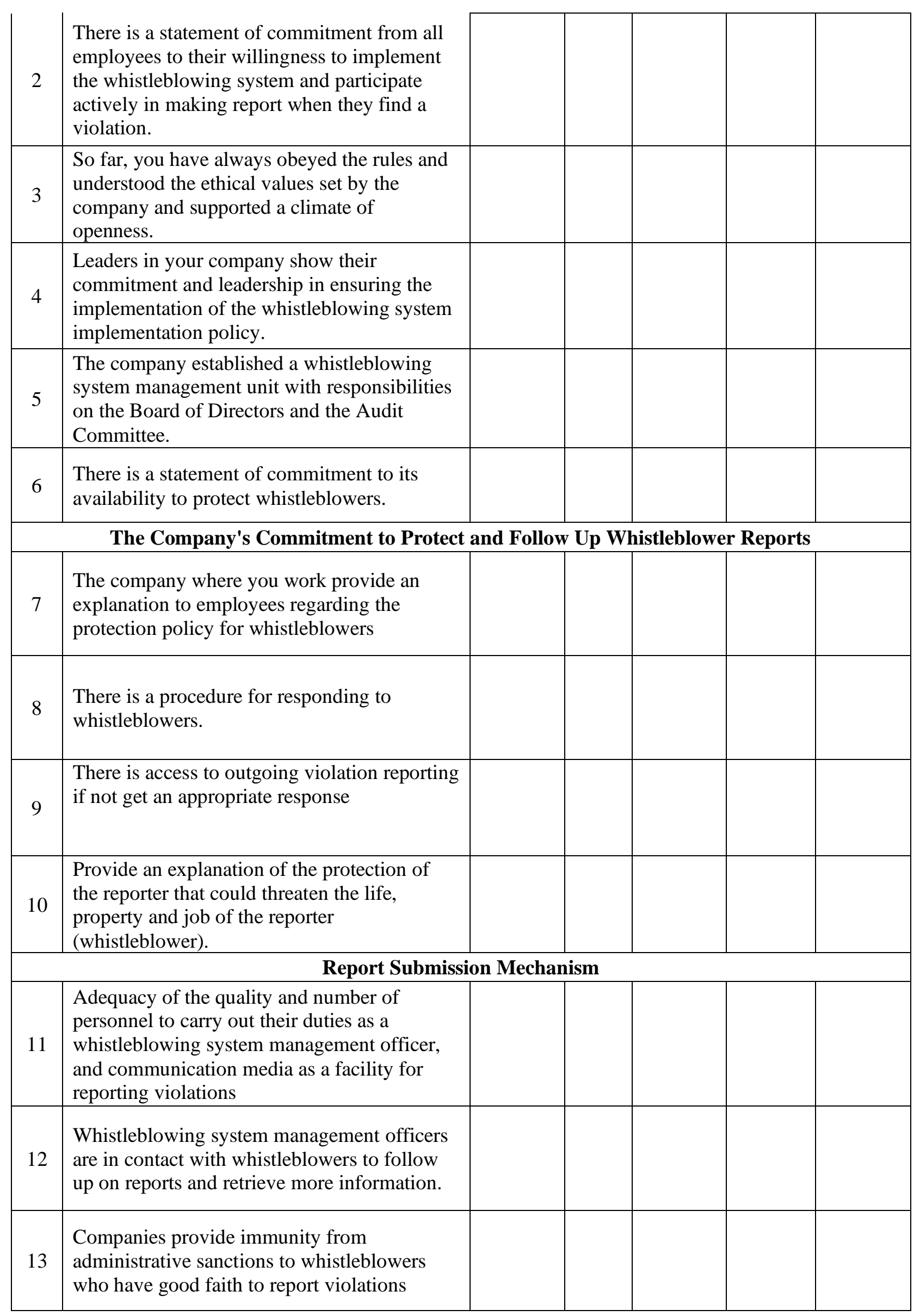

2021 | International Journal of Financial, Accounting, and Management/ Vol 2 No 4, 275-294 


\begin{tabular}{|c|l|l|l|l|l|}
14 & $\begin{array}{l}\text { The submission of violation reports is made } \\
\text { with a mechanism that makes it easier for } \\
\text { employees to submit violation reports }\end{array}$ & $\begin{array}{l}\text { The whistleblowing system implementation } \\
\text { officer will conduct an investigation as soon } \\
\text { as possible by collecting evidence related to } \\
\text { the reported case. }\end{array}$ & & & \\
\hline 16 & $\begin{array}{l}\text { The implementation of the whistleblowing } \\
\text { system is regularly monitored for its } \\
\text { effectiveness. }\end{array}$ & & & & \\
\hline
\end{tabular}

\section{FRAUD PREVENTION (Y)}

\begin{tabular}{|c|c|c|c|c|c|c|}
\hline \multirow[b]{2}{*}{ No. } & \multirow[b]{2}{*}{ Questions } & \multicolumn{5}{|c|}{ Answers } \\
\hline & & $\begin{array}{c}\text { STRONGLY } \\
\text { AGREE }\end{array}$ & AGREE & DOUBTFUL & DISAGREE & $\begin{array}{l}\text { STRONGLY } \\
\text { DISAGREE }\end{array}$ \\
\hline \multicolumn{7}{|c|}{ Reducing Situational "Pressure" that Cause Fraud } \\
\hline 17 & $\begin{array}{l}\text { The company where you work avoid external } \\
\text { pressures that might tempt employees to create } \\
\text { misleading data }\end{array}$ & & & & & \\
\hline 18 & $\begin{array}{l}\text { The company where you work remove } \\
\text { operational barriers that are holding back external } \\
\text { financial performance such as working capital } \\
\text { barriers. }\end{array}$ & & & & & \\
\hline 19 & $\begin{array}{l}\text { The company where you work establish clear and } \\
\text { uniform accounting procedures. }\end{array}$ & & & & & \\
\hline 20 & $\begin{array}{l}\text { The company where you work has created a good } \\
\text { work environment by appreciating work } \\
\text { performance. }\end{array}$ & & & & & \\
\hline \multicolumn{7}{|c|}{ Reducing the "chance" of fraud } \\
\hline 21 & $\begin{array}{l}\text { The company where you work has improved } \\
\text { controls both in the design of the control } \\
\text { structure and in its implementation. }\end{array}$ & & & & & \\
\hline 22 & $\begin{array}{l}\text { The company where you work carefully monitors } \\
\text { business transactions \& personal relationships. }\end{array}$ & & & & & \\
\hline 23 & $\begin{array}{l}\text { The company where you work for has been } \\
\text { Maintained accurate personnel records \& perform } \\
\text { new employee background testing. }\end{array}$ & & & & & \\
\hline 24 & $\begin{array}{l}\text { The existence of strict and indiscriminate } \\
\text { sanctions against perpetrators of fraud. }\end{array}$ & & & & & \\
\hline
\end{tabular}




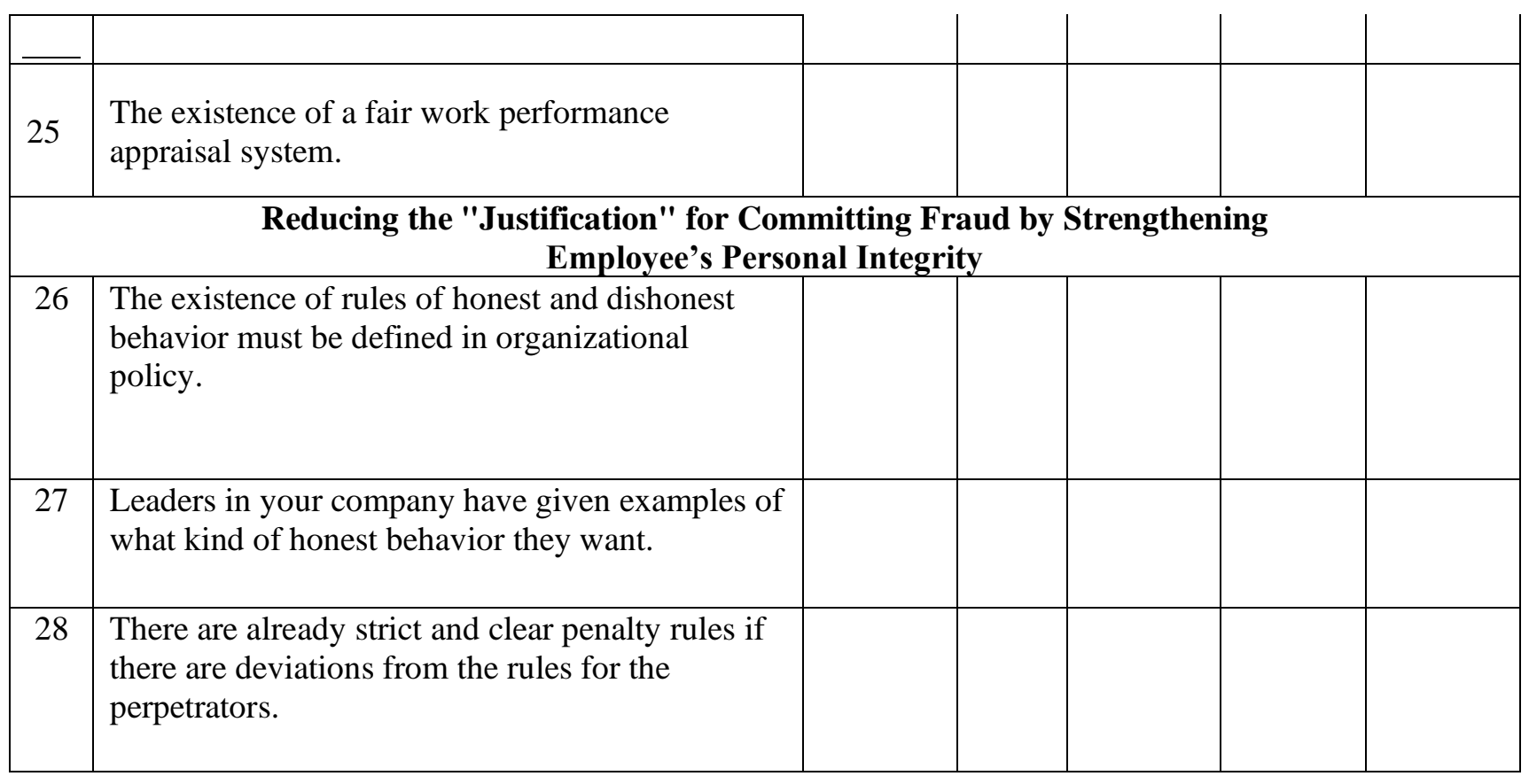

\section{Literature Research}

This technique was intended to obtain library data by studying literature related to the problem being examined in the form of books, journals, and papers related to research.

3. Internet research

In this study, the authors tried to collect data from sites that deal with various kinds of information needed in research.

\section{Research Instruments}

In this study, the research instruments were taken from Semendawai et al.'s (2011) and Karyono's (2013) research as information that could be obtained and studied in order to draw conclusions. In this study, there was an independent variable, which was the implementation of the Whistleblowing System symbolized by X. Meanwhile, the dependent variable was Fraud Prevention symbolized by Y.

\section{Scale of Measurement}

The technique for measuring the ordinal scale was to use a Likert scale measurement. Likert scale is used to measure attitudes, opinions and perceptions of a person or group of people about social phenomena. With these measurements, respondents chose one answer from five scales ranging from lowest to highest which they considered right (Sugiyono, 2018:163) with details as follow:

- $\quad$ Score 5 for strongly agree

- $\quad$ Score 4 for agree

- $\quad$ Score 3 for doubtful

- Score 2 for disagree

- Score 1 for strongly disagree

\section{Results and discussions Overview of respondents}

To explain the background of the respondents who were sampled in this study, a profile description table was made. The description of the respondent's profile consists of gender, age, level of education, and length of work. The data obtained by the author regarding the profile of respondents is as follows: 
Table 2: Classification of Respondents by Gender

\begin{tabular}{|c|c|c|}
\hline Gender & Frequencv & Percentage \\
\hline Men & 17 & $56.67 \%$ \\
\hline Woman & 13 & $43.33 \%$ \\
\hline Total & 30 & $100 \%$ \\
\hline
\end{tabular}

Based on the table above, from the total 30 people who became respondents in this study, it was seen that there were more male respondents than women by $56.67 \%$, while women was $43.33 \%$. The table above shows that the majority of employees in the internal control unit, risk management, strategic planning, and law were mostly male. That is because the part demands performance and has a high level of under pressure.

Table 3: Group of Respondents by Age

\begin{tabular}{|c|c|c|}
\hline Age & Frequency & Percentage \\
\hline$<25$ & 3 & $10,00 \%$ \\
\hline $25-35$ & 8 & $26,67 \%$ \\
\hline $36-46$ & 10 & $33,33 \%$ \\
\hline $46-55$ & 7 & $23,33 \%$ \\
\hline$>56$ & 2 & $6,67 \%$ \\
\hline Total & 30 & $100 \%$ \\
\hline
\end{tabular}

Based on the table above, among the 30 people who became the respondents in this study, it was seen that most respondents were aged 36-46 years old by $33.33 \%$, while respondents with the least age were $>56$ years by $6.67 \%$. The table above shows that the majority of employees in the internal oversight unit, risk management, strategic planning and law have ages between 36-46 years. That is because at that age employees have sufficient knowledge, skills and work experience in supporting the work.

Table 4: Respondent Based on Latest Education

\begin{tabular}{|c|c|c|}
\hline Educational Stage & Frequency & Percentage \\
\hline Diploma & 9 & $30.00 \%$ \\
\hline Undergraduate & 13 & $43.33 \%$ \\
\hline Graduate & 8 & $26.67 \%$ \\
\hline Postgraduate & 0 & $0 \%$ \\
\hline Total & 30 & $100 \%$ \\
\hline
\end{tabular}

Based on the table above, among 30 people who became respondents in this study, it was seen that most respondents had undergraduate education status by $43.33 \%$, while respondents with the least educational status were graduate which was $26.67 \%$. From the table above, it shows that employees in the section of the internal supervisory unit, risk management, strategic planning, and legal majority have an undergraduate education. This is because education is one of the important factors in the minimum requirements of employment.

Table 5: Group of Respondents Based on Length of Work

\begin{tabular}{|c|c|c|}
\hline Length of Work & Frequency & Percentage \\
\hline $1-5$ Years & 4 & $13.33 \%$ \\
\hline 6-10 Years & 13 & $43.33 \%$ \\
\hline $11-15$ Years & 5 & $16.67 \%$ \\
\hline$>15$ Years & 8 & $26.67 \%$ \\
\hline
\end{tabular}


Based on the table above, among 30 people who became respondents in this study, it was seen that the respondents with the most length of working time were 6-10 years at $43.33 \%$, while the respondents who had worked at least 1-5 years was $13.33 \%$. From the table above, it shows that employees in the internal control unit, risk management, strategic planning, and the majority of law has been working for 6-10 years. This means that the length of work can describe a person's experience in mastering his field of work. In general, employees with a lot of work experience do not need guidance compared to officers with little work experience. The longer a person works in an organization, the more experienced the person is so that his work skills are getting better.

\subsection{Validity test}

Validity testing is done by correlating the respondent's answer score for each question. The value of $r$ count is compared to $r$ table, if $r$ count $>r$ table it can be concluded that the data is valid. Based on the validity test conducted on questionnaire questions from the whistleblowing system variables, the following result was obtained:

Table 6: Validity of Whistleblowing System Variable

\begin{tabular}{|c|c|c|c|}
\hline Question Item & $\mathrm{r}$ count & $\mathrm{r}$ table & Information \\
\hline P1 & 0.972 & 0.361 & Valid \\
\hline P2 & 0.964 & 0.361 & Valid \\
\hline P3 & 0.975 & 0.361 & Valid \\
\hline P4 & 0.974 & 0.361 & Valid \\
\hline P5 & 0.843 & 0.361 & Valid \\
\hline P6 & 0.972 & 0.361 & Valid \\
\hline P7 & 0.959 & 0.361 & Valid \\
\hline P8 & 0.836 & 0.361 & Valid \\
\hline P9 & 0.885 & 0.361 & Valid \\
\hline P10 & 0.972 & 0.361 & Valid \\
\hline P11 & 0.959 & 0.361 & Valid \\
\hline P12 & 0.975 & 0.361 & Valid \\
\hline P13 & 0.843 & 0.361 & Valid \\
\hline P14 & 0.885 & 0.361 & Valid \\
\hline P15 & 0.974 & 0.361 & Valid \\
\hline P16 & 0.975 & 0.361 & Valid \\
\hline
\end{tabular}

Based on the validity test of the whistleblowing system variable, it met the validity criteria, namely the value of $r$ count $>r$ table. As for the results of testing the fraud prevention variables is as follows:

Table 7: Validity of Fraud Prevention Variable

\begin{tabular}{|c|c|c|c|}
\hline Item Question & $\mathrm{r}$ count & $\mathrm{r}$ table & Information \\
\hline P1 & 0.748 & 0.361 & Valid \\
\hline P2 & 0.895 & 0.361 & Valid \\
\hline P3 & 0.967 & 0.361 & Valid \\
\hline P4 & 0.986 & 0.361 & Valid \\
\hline P5 & 0.989 & 0.361 & Valid \\
\hline P6 & 0.979 & 0.361 & Valid \\
\hline
\end{tabular}




\begin{tabular}{|c|c|c|c|}
\hline Item Question & $\mathrm{r}$ count & $\mathrm{r}$ table & Information \\
\hline P7 & 0.989 & 0.361 & Valid \\
\hline P8 & 0.972 & 0.361 & Valid \\
\hline P9 & 0.986 & 0.361 & Valid \\
\hline P10 & 0.761 & 0.361 & Valid \\
\hline P11 & 0.972 & 0.361 & Valid \\
\hline P12 & 0.986 & 0.361 & Valid \\
\hline
\end{tabular}

Based on the validity test of the fraud prevention variable, it meets the validity criteria, namely $r$ count $>\mathrm{r}$ table.

\section{Reliability test}

Reliability tests can be done together on all items for more than one variable. The reliability test results for the whistleblowing system variable are as follows:

Table 8: Reliability of Whistleblowing System Variable

\begin{tabular}{|c|c|c|}
\hline \multicolumn{3}{|c|}{ Reliability Statistics } \\
\hline $\begin{array}{c}\text { Cronbach's } \\
\text { Alpha }\end{array}$ & $\begin{array}{c}\text { Cronbach's } \\
\text { Alpha Based on } \\
\text { Standardized } \\
\text { Items }\end{array}$ & $\mathrm{N}$ of Items \\
\hline .990 & .992 & 16 \\
\hline
\end{tabular}

From the table above the reliability value of the whistleblowing system variable was 0.990 , because $r$ was $>0.60$, then the whistleblowing system variable met the reliable criteria. Meanwhile, the results of testing the reliability of fraud prevention variables are as follows:

Table 9: Reliability of Fraud Prevention Variable

\section{Reliability Statistics}

\begin{tabular}{|r|r|r|}
\hline \multicolumn{1}{|c|}{$\begin{array}{c}\text { Cronbach's } \\
\text { Alpha }\end{array}$} & $\begin{array}{c}\text { Cronbach's } \\
\text { Alpha Based on } \\
\text { Standardized } \\
\text { Items }\end{array}$ & \\
\hline .987 & N of Items \\
\hline
\end{tabular}

Based on the table above, the reliability value of fraud prevention variable is 0.987 , because $\mathrm{r}$ was > 0.60 , then the fraud prevention variable met reliable criteria.

\section{Normality test}

Table 10: Kolmogorov Smirnov Normality Test

One-Sample Kolmogorov-Smirnov Test

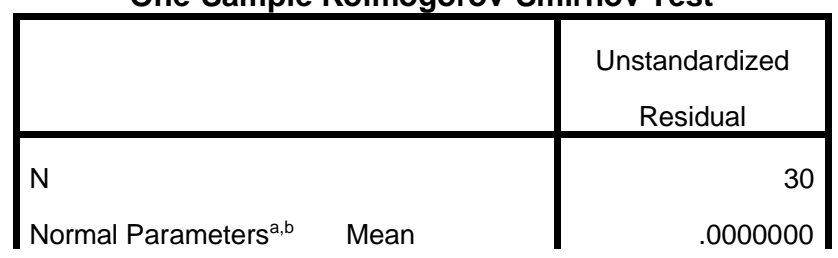




\begin{tabular}{|ll|r|} 
& Std. Deviation & 9.79650762 \\
Most Extreme & Absolute & .084 \\
Differences & Positive & .084 \\
& Negative & -.084 \\
Kolmogorov-Smirnov Z & & .461 \\
Asymp. Sig. (2-tailed) & & .983 \\
\hline
\end{tabular}

Based on table 1 above, it shows that the value of Kolmogrov Smirnov was 0.461 with a significance value of 0.983 . Because the significance value produced by Kolmogrov Smirnov was more than or $10 \%$ (the significance level of research significance) which was $(0.983>0.1)$, it can be concluded that Ho was accepted or residual data were normally distributed. in other words, the regression model was feasible to use because it fulfilled the assumption of normality or normally distributed data.

\section{Heteroscedasticity test}

One way to detect the presence or absence of heteroscedasticity was by look at a scatterplot graph. The following is the results of heteroscedasticity testing using scatterplot graphs:

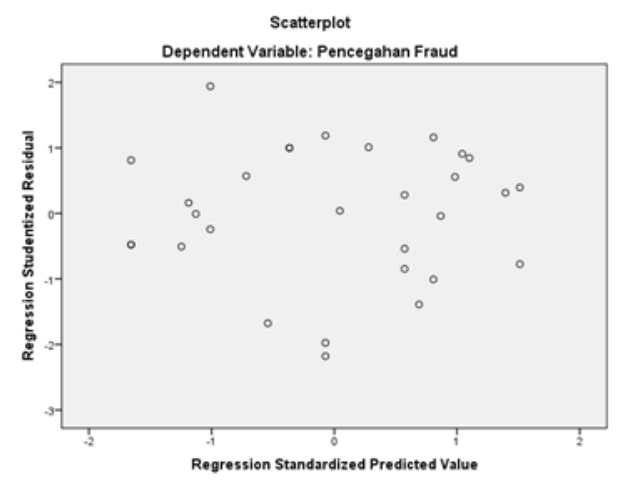

Figure 2: Heteroscedasticity Test

Based on the scatter plot test results in Figure 1 it can be seen that there are no clear patterns and points spread between below 0 to above 0 on the $\mathrm{Y}$ axis. It can be concluded that there as no heteroscedasticity in the regression model.

\section{Simple Regression Analyst}

Table 11: Simple Regression Analyst Coefficients $^{\mathrm{a}}$

\begin{tabular}{|c|c|c|c|c|c|}
\hline \multirow[b]{2}{*}{ Model } & \multicolumn{2}{|c|}{$\begin{array}{c}\text { Unstandardized } \\
\text { Coefficients }\end{array}$} & \multirow{2}{*}{$\begin{array}{c}\text { Standardized } \\
\text { Coefficients } \\
\text { Beta }\end{array}$} & \multirow[b]{2}{*}{$\mathrm{t}$} & \multirow[b]{2}{*}{ Sig. } \\
\hline & $\mathrm{B}$ & Std. Error & & & \\
\hline 1 (Constant) & 6.148 & 6.167 & & .997 & .327 \\
\hline Whistleblowing System & .627 & .109 & .737 & 5.767 & .000 \\
\hline
\end{tabular}

The regression equation model that is formed based on the results of the study are:

$$
\mathrm{Y}=6.148+0.627 \mathrm{X}+\mathrm{e}
$$


1. If the constant value is 6.148 , it means that the independent variable, which is the whistleblowing system variable, is considered constant (value 0), then the dependent variable, which is the fraud prevention variable, will be worth 6.148.

2 . If the regression coefficient value of the whistleblowing system variable shows 0.627 , it means that if the whistleblowing system variable increases by (one) unit, the dependent variable, namely the fraud prevention variable, will increase by 0.627 .

\section{Hypothesis test}

Based on the results of the $t$ test (partial) in the regression model, the significance value of the whistleblowing system variable is $0.000<0.1$ (the significance level of research significance). Besides that, it can also be seen from the result of the comparison between $t$ count and table which shows the $t$ count value of 5.767 , while $t$ table is 1.703 . From these results, it can be seen that $t$ count $>\mathrm{t}$ table is $5.767>1.703$, it can be concluded that Ha is accepted, meaning that partially, the whistleblowing system variable has a significant effect on fraud prevention.

\section{Coefficient of Determination Analysis}

Table 12: Coefficient of Determination

\begin{tabular}{|l|r|r|r|}
\hline & & & \multicolumn{1}{|c|}{ Model Summary } \\
\hline Model & $\mathrm{R}$ & R Square & \multicolumn{1}{c|}{ Square } \\
\hline 1 & $.737^{\mathrm{a}}$ & .543 & .527 \\
\hline
\end{tabular}

Based on the results of testing the coefficient of determination in the table above, it shows that the R2 value is 0.543 , which means that the variability of the dependent variable, namely fraud prevention can be explained by the independent variable. The whistleblowing system variable in this study was $54.3 \%$, while the remaining $45.7 \%$ is explained by other variables outside the research model.

\section{Overview of Whistleblowing System in Jabar Banten Central Bank in Bandung}

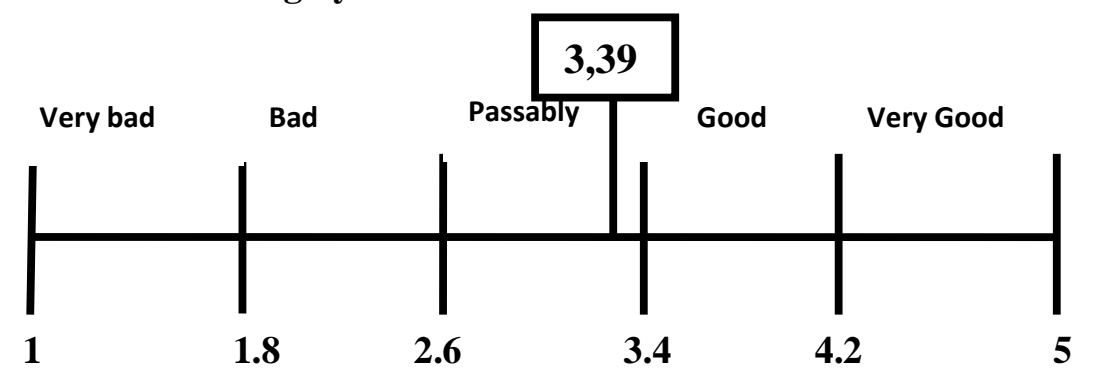

Figure 3: Continuum Line Categorization Rating Whistleblowing System Variable

Based on the results of research on the whistleblowing system, it showed that the total value of the actual score obtained from assessments that made up the whistleblowing system variable was 1.627 and the ideal score is 2.400 , while the total value of the contribution obtained was $67.79 \%$ and the average score of 3.39 was categorized in the passably category. This showed that the application of the whistleblowing system shown by Jabar Banten Central Bank in Bandung was included in the passably category.

The dimensions of company and employees' commitment show a mean score of 3.26 which was categorized as passable. This shows that the commitment shown by the company and all employees in practicing the whistleblowing system by implementing a violation reporting system has been running 
quite well. The dimension of the company's commitment to protect and follow up on the whistleblower report shows a mean score of 3.55 which was categorized good. This shows that the company in following up on reports from whistleblowers and committed to protect whistleblowers was running well. The dimension of report submission mechanism shows mean score of 3.42 which was categorized as good. This shows that the company's roles which are to create a mechanism for whistleblowers in delivering reports of alleged customers by providing infrastructure and reporting mechanisms, safeguarding the reporter's identity and guard against penalty, communicating with reporters, investigating whistleblower reports, and ensuring that reports were handled well by the company.

\section{Overview of Fraud Prevention in Jabar Banten Central Bank in Bandung}

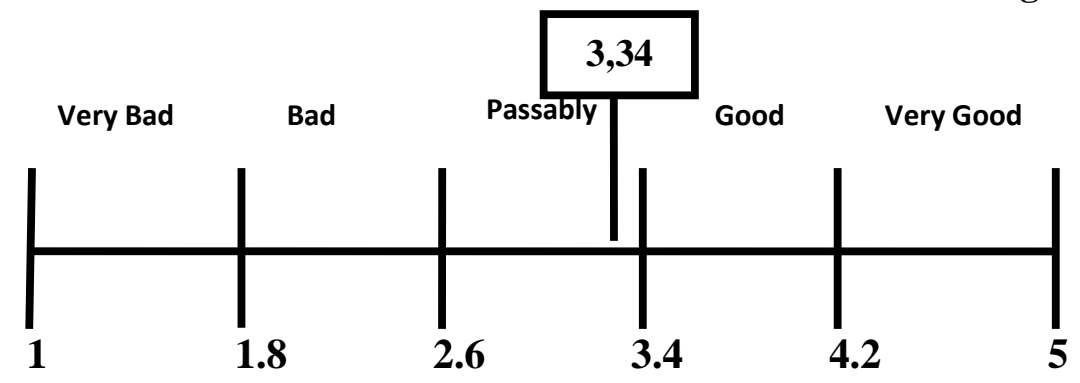

Figure 4: Continuum Line Categorization Rating Fraud Prevention Variable

Based on the results of research on fraud prevention, it shows that the total actual score obtained from all statements that made up the fraud prevention variable was 1.204 and the ideal score was 1.800 , while the total percentage value obtained was $66.89 \%$ and the mean score was $3.34 \%$ categorized in good categories. This shows that fraud prevention shown by Jabar Banten Central Bank in Bandung was included in the passably category. Fraud prevention which consists of the dimensions of reducing situational "pressure" that creates fraud, the dimension of reducing the "opportunity" of cheating, and the dimension of reducing "justification" of cheating by strengthening employee personal integrity.

The three dimensions show that the dimension of reducing the "chance" of cheating, shows the lowest mean score below the mean value of the score compared to the dimension of reducing situational "pressure" that creates fraud and the dimension of reducing "justification" of cheating by strengthening personal integrity employee seen from the respondent's answers to several statements that indicate the existence of respondents who answered disagree and strongly disagree on the statement in each statement in the dimensions of the fraud prevention variable. This means that, even though fraud prevention shown by Jabar Banten Central Bank in Bandung was categorized in the passably category, it still shows weaknesses in fraud prevention at Jabar Banten Central Bank in Bandung which still needs to be addressed.

This is related to the reduction of situational "pressure" that creates fraud, namely the accounting procedures established in the company which are unclear and uniform. In addition, the company does not reward employees who excel. With regard to reduce the "opportunity" to commit fraud, namely the control system and structural design, there are still loopholes to commit fraud, lack of supervision of the transaction documentation section. Sanctions are not too strict so they do not provide a deterrent effect for fraudsters. Besides related to reducing the "justification" of fraud by strengthening the personal integrity of employees, the leader does not set a good example to his subordinates and impose sanctions that are not too strict. 


\section{The Effect of Whistleblowing System on Fraud Prevention}

Based on the results of the study, it showed that the whistleblowing system had a significant effect on fraud prevention. Meanwhile, the magnitude of the influence of the whistleblowing system in contributing influence to fraud prevention was $54.3 \%$. The results of this study are supported by the theoretical basis in the previous discussion which states that fraud is any illegal act characterized by fraud, concealment, or abuse of trust. Such actions are not limited to threats or violations in the form of physical force. Fraud can be committed by parties and organizations to get money, assets, or services; to avoid payment or loss of services; or for personal or business gain (The Institute of Internal Auditors, 2017).

Researchers agree that whistleblowing is an important medium to prevent and deter company mistakes (Bhal \& Dadhich, 2011). Anti Fraud Control which was published based on the results of ACFE in 2016 stated the best and most effective fraud prevention method is through the Whistleblowing System. Anti-fraud strategy for conventional and Islamic banks in its application is in the form of detection and prevention. Detection and prevention are part of a fraud control system that contains steps in order to identify and find fraud in the Bank's business activities, which includes Whistleblowing policies, surprise audits, and a monitoring system (Association of Certified Fraud Examiners Indonesia Chapter, 2016).

An effective whistleblowing system will encourage public participation and company employees to be more courageous in taking action to prevent fraud and corruption by reporting it to parties who can handle it. This means that the Whistleblowing System is able to reduce the culture of "silence" towards a culture of "honesty and openness". The effectiveness of the Whistleblowing System can be seen from the number of frauds detected and also the relatively shorter time to act than other methods (Komite Nasional Kebijakan Governance, 2008). A study results showed that fraud was detected more through information from fellow employees than was found by auditors.

The results of this study are in line with the results of previous studies conducted by Wardana et al. (2017), Atmadja et al. (2019), Nurfadillah (2018), Sabdelino (2016), Yuniarti (2017), Ramdhani (2018), Pamungkas et al. (2017), and (Purnamawati, 2018). The results of his research show that the whistleblowing system has an effect on fraud prevention. Meanwhile, the results of this study are not in line with the results of previous studies conducted by Atmadja et al. (2019). The results of his research show that the whistleblowing system has no effect on fraud prevention.

\section{Conclusion}

Based on the results of research and discussion, the following conclusions are obtained:

1. The results of the study show that the application of the whistleblowing system shown by Jabar Banten Central Bank in Bandung is categorized in the passable category.

2. The results of the study indicated that fraud prevention shown by Jabar Banten Central Bank in Bandung is categorized in the passable category.

3. The results of the study suggest that the application of the whistleblowing system has an effect on fraud prevention in the Jabar Banten Central Bank in Bandung.

\section{Improving the Application of Whistleblowing System}

1. Improving the application by establishing a control system in preventing the practice of irregularities and fraud by exposing violations that violate the law, unethical and immoral acts.

2. Providing education about the benefits of implementing a Whistleblowing system that is useful in preventing fraud.

3. Understanding the ethical values established to support a climate of openness and ensure the implementation of control.

4. There is access to reporting violations out if they do not get the appropriate response. A good mechanism that can facilitate employees in submitting reports of violations 


\section{Fraud Prevention}

1. Improving fraud prevention by establishing a reporting system to facilitate and encourage reporting of potential fraud Eliminating operational obstacles that restrain external financial performance such as working capital constraints.

2. Work performance increases better fraud prevention.

3. Monitor the business transactions \& personal relationships carefully

\section{References}

Alfian, N., Subhan, \& Rahayu, R. P. (2018). Penerapan whistleblowing aystem dan surprise audit sebagai strategi anti fraud dalam industri perbankan. Jurnal Akuntansi Muhammadiyah, 8(2), 18. https://doi.org/10.1017/CBO9781107415324.004

Association of Certified Fraud Examiners. (2018). Global Study on Occupational Fraud and Abuse: Goverment Edition. Report to the Nations. Austin.

Association of Certified Fraud Examiners Indonesia Chapter. (2016). Survai Fraud Indonesia 2016. Jakarta. https://doi.org/10.1201/9781315178141-3

Atmadja, A. T., Saputra, K. A. K., \& Manurung, D. T. H. (2019). Proactive fraud audit, whistleblowing and cultural implementation of tri hita karana for fraud prevention. European Research Studies Journal, 22(3), 201-214.

Bank BJB. (2020). Whistle Blowing System Divisi Audit Internal Bank BJB - bjbWbs. Retrieved March 4, 2020, from https://bjbwbs.bankbjb.co.id/

Bayunitri, B. I., \& Christinawati, A. (2019). The influence of internal auditor skills on fraud detection (Survey at PT. Bank Mandiri cabang Soekarno-Hatta Bandung, Bandung, Indonesia). International Journal of Innovation, Creativity and Change, 6(12), 24-31.

Bhal, K. T., \& Dadhich, A. (2011). Impact of ethical leadership and leader-member exchange on whistle blowing: The moderating impact of the moral intensity of the issue. Journal of Business Ethics, 103(485). https://doi.org/https://doi.org/10.1007/s10551-011-0876-z

Director Regulation No. 002/PBSG-SKAI/DIR/IV/2017 (2017) Company Guidelines for Reporting System of Violations through the Whistleblowing System (WBS). The Republic of Indonesia.

Karyono. (2013). Forensic Fraud. Yogyakarta: CV. Andi Offset.

Kennedy, P. S. J., \& Siregar, S. L. (2017). Fraud actors in Indonesia according to fraud Indonesia survey. Buletin Ekonomi FEUKI, 21(2), 50-58.

Komite Nasional Kebijakan Governance. (2008). Pedoman Sistem Pelaporan Pelanggaran - SPP (Whistleblowing System - WBS). Jakarta. Retrieved from http://www.knkgindonesia.org/dokumen/Pedoman-Pelaporan-Pelanggaran-Whistleblowing-System-WBS.pdf

Libramawan, I. P. (2014). Pengaruh Penerapan Whistleblowing System terhadap Pencegahan Kecurangan (Studi Survey pada PT Coca-Cola Amatil Indonesia SO Bandung). Universitas Widyatama.

Merdikawati, R., \& Prastiwi, A. (2012). Hubungan Komitmen Profesi dan Sosialisasi Antisipatif Mahasiswa Akuntansi dengan Niat Whistleblowing (Studi Empiris pada Mahasiswa Strata 1 Jurusan Akuntansi di Tiga Universitas Negeri Teratas di Jawa Tengah dan DI Yogyakarta). Diponegoro University.

Novatiani, R. A., \& Julaeha, E. (2013). Internal audit influence to fraud prevention (A case study at PT. PINDAD, Bandung-Indonesia). In International Innovative Scientific and Research Organisation International Multi-Conference 2013 (pp. 112-115). Pattaya.

Nurfadillah, H. (2018). Pengaruh Penerapan Whistleblowing System terhadap Pencegahan Kecurangan (Fraud) (Studi Kasus pada Kantor Pengawasan dan Pelayanan Beda dan Cukai Tipe Madya Pabean A Bandung). Universitas Widyatama.

Pamungkas, I. D., Ghozali, I., \& Achmad, T. (2017). The effects of the whistleblowing system on financial statements fraud: Ethical behavior as the mediators. International Journal of Civil Engineering and Technology, 8(10), 1592-1598.

Purnamawati, I. G. A. (2018). Individual perception of ethical behavior and whistleblowing on fraud detection through self-efficacy. Jurnal Keuangan Dan Perbankan, 22(2), 362-372. https://doi.org/10.26905/jkdp.v22i2.1991

Ramdhani, R. (2018). Pengaruh Audit Internal dan Whistleblowing System terhadap Pencegahan 2021 | International Journal of Financial, Accounting, and Management/ Vol 2 No 4, 275-294 
Kecurangan (Fraud) (Studi Kasus Pada PT. PLN (Persero) Distribusi Jawa Barat). Pasundan University.

Sabdelino, S. (2016). Pengaruh Auditor Internal dalam Penerapan Whistleblowing System terhadap Pencegahan Kecurangan (Studi Kasus PT Bio Farma). Universitas Widyatama.

Semendawai, A. H., Santoso, F., Wagiman, W., Omas, B. I., Susilaningtias, \& Martanto, S. W. (2011). Memahami Whistleblower. Lembaga Perlindungan Saksi dan Korban.

Sugiyono. (2018). Metode Penelitian Pendidikan: Pendekatan Kuantitatif, Kualitatif, dan R\&D. Bandung: Alfabeta.

The Institute of Internal Auditors. (2017). International Professional Practices Framework. Florida: The Internal Audit Foundation.

Umar, H. (2010). Desain Penelitian Manajemen Strategik: Cara Mudah Meneliti Masalah-Masalah Manajemen Strategik untuk Skripsi, Tesis, dan Praktik Bisnis. Jakarta: Rajawali Pers.

Wardana, I. G. A. K., Sujana, E., \& Wahyuni, M. A. (2017). Pengaruh pengendalian internal, whistleblowing system dan moralitas aparat terhadap pencegahan fraud pada dinas pekerjaan umum kabupaten Buleleng. Jurnal Ilmiah Mahasiswa Akuntansi Undiksha, 8(2), 1-10.

Wijaya, E. (2019). Pengaruh Audit Internal dan Whistleblowing System Terhadap Pencegahan Kecurangan pada PT Bank x Tbk. STIE Ekuitas.

Yuniarti, R. D. (2017). The effect of internal control and anti-fraud awareness on fraud prevention (A survey on inter-governmental organizations). Journal of Economics, Business, and Accountancy Ventura, 20(1), 113-124. https://doi.org/10.14414/jebav.v20i1.626 